\title{
Vergi Mevzuatı Çerçevesinde Muhasebe Hata ve Hilelerine Bakış: Muhasebe Meslek Mensuplarına Yönelik Bir Araştırma*
}

\section{An Overview of Accounting Errors and Fraud within the Framework of Tax Legislation: Evidence from Accounting Professionals}

\author{
Mert Can Uslu ${ }^{1}$ (D), Deniz Özbay ${ }^{2}$ (D)

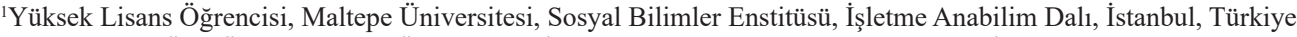 \\ ${ }^{2}$ Dr. Öğr. Üyesi, Maltepe Üniversitesi, İşletme ve Yönetim Bilimleri Fakültesi, İstanbul, Türkiye \\ ORCID: M.U. 0000-0002-2324-6877; D.Ö. 0000-0003-4643-7577 \\ *Bu çalışma, "Muhasebe Hata ve Hilelerinin Türk Vergi Mevzuatı Bakımından Değerlendirilmesi” başlıklı yüksek lisans tezinden türetilmiştir.
}

\section{ÖZ}

Küreselleşmenin, artan rekabetin ve teknolojik ilerlemelerin etkisiyle çeşitleri ve yapılış şekillerinde değişiklikleler olsa da, muhasebe hata ve hileleri, geçmişten günümüze işletmelerin kaçınılamaz bir problemi olarak varlığını korumaktadır. Çalışmanın amacı, muhasebe meslek mensuplarının muhasebe hata ve hilelerine bakışlarında, vergi düzenlemelerinin etkisini değerlendirmektir. Bu değerlendirme yapılırken İstanbul'da serbest muhasebeci mali müşavir olarak faaliyetlerini yürüten meslek mensuplarının bakış açılarını ortaya koymaya yönelik bir araştırma gerçekleştirilmiştir. Araştırma bulgularına göre, muhasebe hata ve hilelerinin ortaya çıkışında vergi mevzuatı ve vergi baskısı en önemli faktörler arasında değerlendirilirken, muhasebe meslek mensuplarının yaş, eğitim seviyesi, bağımlı ya da bağımsız çalışma durumları ve mesleki tecrübelerinden bağımsız olarak vergiyi ön planda tutan bir anlayış içinde oldukları görülmüştür.

Anahtar kelimeler: Muhasebe hataları, muhasebe hileleri, vergi mevzuatı

\section{ABSTRACT}

Although there are some differences in the types and ways of accounting errors and fraud due to the effects of globalisation, competition and technological development, these two concepts have remained an inevitable problem of business from past to present. The aim of the study is to evaluate the effect of tax regulations on the professional accountant's view of errors and fraud. In accordance with this purpose, a research was carried out to reveal the perspectives of the professionals in İstanbul. According to the findings, professional accountants consider tax legislations and tax pressure among the most important factors in the emergence of accounting faults and fraud. Additionally, it is seen that they prioritise tax regardless of their age, education level, employment status and/or professional experience.

Keywords: Accounting errors, accounting frauds, tax legislation

Başvuru/Submitted: 21.05.2020 Revizyon Talebi/Revision Requested: 26.06.2020 Son Revizyon/Last Revision Received: 01.07.2020 Kabul/Accepted: 16.07.2020 Sorumlu yazar/Corresponding author: Mert Can Uslu / mertcanuslu1@gmail.com

Atıf/Citation: Uslu M.C. \& Özbay D. (2020). Vergi mevzuatı çerçevesinde muhasebe hata ve hilelerine bakış: muhasebe meslek mensuplarına yönelik bir araştırma. Muhasebe Enstitüsü Dergisi - Journal of Accounting Institute, 63, 21-32. https://doi.org/doi.org/10.26650/MED.740880 


\section{Extended Abstract}

The aim of the study is to evaluate the effect of tax regulations on the professional accountant's view of errors and fraud. In this context, this study has searched for answers to the following questions.

RQ1: Is there any relationship between the demographic characteristics of professional accountants and their behaviour to prioritise tax in the decision making process?

RQ2: Is tax legislation one of the factors that promotes or prevents accounting errors and fraud?

RQ3: Does the tax prioritisation behaviour of professional accountants depend on being self-employed or working for a company?

RQ4: What encourages people to commit accounting errors and fraud? What are the factors that are effective in preventing errors and fraud?

Although there are some differences in the types and ways of accounting errors and fraud due to the effects of globalisation, competition and technological development, these two concepts have remained an inevitable problem of business from past to present. While accounting errors refer to the mistakes made in the accounting records or books due to professional illiteracy, carelessness and inexperience; accounting error refers to intentional irregularities for corporate gain or individual benefits. The main stakeholders that can be a part of fraud for the companies are employees, managers and shareholders. There are many factors that tempt these stakeholders into fraud such as opportunity, financial pressure, rationalization, perception and share based payments for managers. The results of some studies suggest that personality traits and rationalisation appear to be a major factors in fraud. Accounting fraud has been extensively studied in literature from past to present. It has been widely discussed within the issues of business ethics and auditing, especially with the influence of large corporate scandals such as Enron, WorldCom and Parmalat. Although accounting fraud has significant effects on taxes which constitute the most important source of income for the Turkish provinces, research on the relationship between fraud and tax legislations are limited in literature. The concept of accounting fraud is not explicitly defined within the scope of Tax Procedure Law (TPL), but it is stated in article 359 of TPL within the actions that require smuggling punishment. Some crimes covered by this article are listed as making changes in accounts, falsifying book records and documents that need to be kept, hiding these documents from the relevant authorities, preparing misleading or false documents, partially or completely destroying books, records and documents. Within the scope of the study, firstly, accounting errors and fraud were examined within the framework of tax legislation, and then, a research about the impact of tax regulations on the professional accountant's view of errors and fraud was included.

A survey model is used in this research. The sample for the research is composed of 202 accounting professionals who are members of the Istanbul Chamber of Certified Public Accountants. The data was collected through the survey which consists of 3 parts: demographic questions, ranking questions and the 5-point Likert scale.

The research findings support the conclusions that professional accountants prioritise tax in the decision making process regardless of their demographic characteristics as well as their employment status. Accounting professionals who participated in the research argued that tax legislation is one of the most important factors in fraud. Therefore, they evaluated problems such as the congestion of the tax calendar, frequent changes in legislation, -and a lack of legislation-, as factors causing errors and fraud. On the other hand, they suggested that there is more shareholder or management fraud than employee fraud in the business. So, it is important that professional standards for fraud detection strengthen the emphasis on any unethical behaviour of managers and shareholders. In addition, it is also important to increase the disincentives in tax laws and to make regulations more understandable and standardised. Professional accountants have a responsibility to detect and prevent fraud, so they must learn the tools and strategies necessary to recognise fraud and to catch it in time. 


\section{Giriş}

Muhasebe hataları, kasıt olmaksızın, bilgisizlik, dikkatsizlik, tecrübesizlik gibi nedenlerle yapılan yanlışlıkları ifade ederken, muhasebe hileleri ise çıkar sağlamak amaçlı ve kasıtlı olarak yapılan usulsüzlükleri ifade etmektedir. Muhasebe hataları, günümüzde özellikle de hata denetimi yapabilen yazılım programları vasıtasıyla önemli ölçüde engellenebilirken, hileyi önlemede daha kapsamlı yaptırımlar gerekmektedir. Muhasebe hileleri tüm dünyada, işletmelerin büyüklüğü veya küçüklüğü fark etmeksizin, belirli çıkarlar güden gruplar veya bireyler tarafından yapılmaktadır. Önlemler alınması, yasalar çıkarılması veya denetim mekanizmalarının doğru bir şekilde işletilmesi gibi faaliyetler, insan doğası gereği hileyi gerçekleştirenleri tamamen engelleyememektedir.

Geçmişten günümüze literatürde yoğun bir şekilde incelenen muhasebe hileleri, özellikle Enron, WorldCom, Parmalat gibi büyük çaplı şirket skandallarının etkisiyle, daha çok işletme etiği ve denetim mekanizmaları gibi konularla birlikte ele alınmış ve araştırmalar da genel olarak bu bağlamda şekillenmiştir. Öte yandan muhasebe hilelerin önemli etkilerinden biri de devletlerin en önemli gelir kaynağını oluşturan vergiler üzerindeki etkileridir.

Çalışma kapsamında ilk olarak vergi mevzuatı çerçevesinde muhasebe hata ve hileleri ele alınmış daha sonra, muhasebe meslek mensuplarının, hata ve hileye bakışlarında verginin etkisini anlamaya yönelik bir araştırmaya yer verilmiştir.

\section{Muhasebe Hata ve Hileleri}

Hata kavramı, istemeyerek ve bilmeyerek yapılan yanlış, kusur, yanılma ve yanılgı olarak tanımlanmaktadır (TDK, 2018). Muhasebe hataları, özünde kasıt unsuru taşımayan fiillerdir. Vergi yasalarına, kayıt düzenine, muhasebe sistemine ve idarenin koymuş olduğu diğer kurallara aykırı bir muhasebe işlemi gerçekleştirilmiş, fakat bilinçli bir şekilde yapılmamıştır. Hatanın kelime anlamında da olduğu gibi, istemeyerek ve bilmeyerek yapılan bir yanlış söz konusudur. Hatanın özünde, suç unsurunun cezasını hafifleten bir kusur hali bulunmaktadır. Bu kusur hali pek çok sebepten kaynaklanabilmektedir. Yeterli mesleki eğitime sahip olmayan bireylerin muhasebe kayıtlarını gerçekleştirmesi, dikkatsizlik, unutkanlık, düzensizlik, plansızlık gibi sebepler hataya yol açabilmektedir.

Muhasebe hataları genel olarak matematik hataları, kayıt hataları, nakil hataları, yanlış hesap kullanımı, rakam yanlışlıkları, unutma ve tekrarlama gibi farklı nedenlerle ortaya çıkmaktadır. Muhasebe hatalarını, içerik bakımından (nicel veya nitel hatalar), sonuçları bakımından (önemli veya önemsiz) ve etkileri bakımından (bilançoya, gelir tablosuna ve her iki tabloya etkisi) olmak üzere üç ana başlık altında da toplamak mümkündür. (Bayraklı, Erkan \& Elitaş, 2012, s. 22; Erdoğan, Elitaş, Erkan \& Aydemir, 2014, s. 70-73; Çaldağ, 2007, s. 39; Batı, 2017, s. 49-51).

Hile kelimesi ise, hatadan farklı olarak "kasıt" içermektedir. İngilizce'de hile terimini ifade eden "fraud", kelimesi Latince'de hasar, yanlış yapma, aldatma kavramları için kullanılan "Fraus" kelimesinden türemiştir. Ülkemizde ise "fraud" kelimesi yerine; hile, yolsuzluk ya da suiistimal kelimeleri kullanılmaktadır (Bat1, 2017, s. 19). Hile, ilk insan zamanından beri var olan ve günümüzde de işletmelerin ciddi tutarlarda zarara uğramalarına ve hatta iflaslarına neden olan birtakım etik dışı eylemlerdir. Her bir hile işlemi genellikle beraberinde etik kurallara aykırılıkları da içermekle beraber, her etik kurala aykırı eylem bir hile değildir (Pehlivanlı, 2011, s. 3).

Kurum tarafından, kurum için ya da kuruma karşı yapılan hile kurumsal hile olarak adlandırılmaktadır (Singleton \& Singleton, 2010, s. 40). İşletme, içerisinde kendisine bağlı birçok yapıyı barındırır. Hilenin ortaya çıkışı da bu yapılarla doğrudan ilgilidir. İşletme için hileye taraf olabilecek temel paydaşlar çalışanlar, yöneticiler ve hissedarlar olarak karşımıza çıkmaktadır. Bu tarafları hileye iten birçok etken olabilmektedir. Örneğin çalışanlar, işletmeden doğrudan ya da dolaylı olarak fayda sağlamaya çalışabilmektedir. Doğrudan fayda işletme kaynaklarını kendi lehine olacak şekilde kullanmakken, dolaylı faydada farklı çıkar gruplarına fayda sağlamak ve bu çıkar gruplarından rant elde etmek söz konusudur (Bozkurt, 2016, s. 64). İşletme çalışanlarını, hile yapmaya iten birçok neden olabilmektedir. Çalışanın borcunun olması, standartları daha yüksek bir hayatın hayalini kurması, paraya hızlı ve çabuk bir şekilde ulaşma isteği, özel nedenler, kötü alışkanlıklar gibi örnekler çoğaltılabilir. Kişilerin hileye yatkınlığı; baskı, fırsat ve kendini haklı gösterme unsurları bir araya geldiği 
zaman da artış gösterebilmektedir (Doğan, 2018, s. 96). 1950’lerde Donald Preston tarafından yapılan bir araştırma, kişileri hileye iten temelde üç faktör olduğu sonucunu ortaya koymuştur. Hile üçgeni olarak adlandırılan bu faktörler; fırsat (opportunity), finansal baskı (financial pressure) ve akla uygun kılma (rationalization) olarak siralanmaktadır (Singleton \& Singleton, 2010, s. 45).

Hileyi gerçekleştiren taraflardan bir diğeri ise yöneticilerdir. Yönetim hileleri olarak adlandırılan bu hile türünde hileyi yapan genel olarak üst düzey yöneticilerdir. Hilenin muhatapları ise işletme hissedarları veya yatırımcıları, devlet kurumları ve kredi verenlerdir. Yönetim hileleri, çalışanlar tarafından gerçekleştirilen hilelere göre, daha sık karşılaşılan bir hile türüdür. Bunun en temel sebebi ise tepe yönetiminin iç denetim ve hile denetimi konusunda işletmede söz ve yetki sahibi olmasıdır (Batı, 2017, s. 24). İşletmelerde iç denetim ve bağımsız denetimin yetersiz olması işletmenin iç kontrol yapısının zayıflamasına sebebiyet vermekte ve hilenin ortaya çıkmasında gerekli ortamın oluşmasına katkı sağlamaktadır (Mengi, 2013, s. 19). Hileyi gerçekleştiren bir diğer taraf ise hissedarlardır. Crocker ve Slemrod (2005), vergi kaçırma üzerine yaptıkları araştırmada vergi yöneticisine verilen cezaların, vergi kaçırma üzerindeki azaltıcı, etkisinin hissedarlara uygulanan cezalardan daha etkin olduğu sonucunu ortaya koymuşlardır (Crocker \& Slemrod, 2005). Dolayısıyla kuralların, prosedürlerin ve denetimlerin artırılması yanında, hilelerin azaltılmasında cezai yaptırımların da etkili olduğu görüşü öne sürülmüştür.

Muhasebe hilesi, belirli bir amaç doğrultusunda işletme veya organizasyonun kayıt, belge ve bilgilerinin isteyerek, bilinçli olarak bozulması ve tahrif edilmesidir. Muhasebe hataları, bilgisizlik ve dikkatsizlik gibi nedenlerle karşımıza çıkarken, muhasebe hileleri bilerek ve isteyerek yapılmaktadır (Maliye Hesap Uzmanları Derneği, 2011, s. 91). Muhasebe hileleri kayıtların kasten değiştirilmesi, kayıt dışı işlemler, gerçek olmayan hesapların kullanımı, belgede sahtecilik, mali tabloların makyajlanması, bilgisayar hileleri ve varlıkların kötüye kullanımı gibi şekillerde karşımıza çıkabilmektedir (Maliye Hesap Uzmanları Derneği, 2011, s. 92; Bayrakl1, Erkan \& Elitaş, 2012, s. 80; Alptekin, 2017, s. 29; Bat1, 2017, s. 41-42). Muhasebe hata ve hilelerini birbirinden ayırt edebilmek güçtür. Bunun en büyük sebebi ise kasıt unsurudur. Muhasebede meydana gelen mevzuata aykırı bir durumda, fiil kasıtlı olarak işlendiği takdirde bu muhasebe hilesidir. Kasıt unsuru olmadığı takdirde ise bu aykırılık yine var olmakla birlikte, hata olarak değerlendirilmektedir. Vergi Usul Kanunu (VUK) açısından bakıldığında, muhasebe hataları değil, muhasebe hileleri cezaya tabidir. Ceza hukukunun genel ilkeleri açısından bakıldığında ise, muhasebe hilelerini gerçekleştirme fiilinin maddi karşılığı; vergi ve muhasebe ilkelerine, aynı zamanda da gerçeğe aykırı muhasebe kayıtları yapılmasıdır. Manevi karşılığı ise, kasten ya da taksirle yapılmış olmasıdır. Aşağıdaki hallerde kast unsurunun varlığından söz edilebilmektedir (Erdoğan ve ark., 2014, s. 68-69):

- Olağandışı durumlar haricinde gerçekleşen önemli düzensizlikler.

- Çift taraflı muhasebe kayıt sistemiyle varlığı tespit edilebilecek bir hatanın, başka bir hatalı kayıt yapılarak örtülmesi. Burada, ilk kayıt hata sonucu gerçekleşmiş olsa bile, ikinci kayıtın varlığı hilenin kanıtıdır.

- Hatanın, süreklilik arz edecek şekilde tekrarlanması.

\subsection{Türk Vergi Mevzuatı Çerçevesinde Muhasebe Hata ve Hileleri}

VUK 116-126. maddeleri arasında vergi hataları ve bu hataların düzeltilmesiyle alakalı kısımlar yer almaktadır. Vergi hatası VUK'da, "vergiye müteallik hesaplarda veya vergilendirmede yapılan hatalar yüzünden, haksız yere fazla veya eksik vergi istenmesi veya alınması" olarak tanımlanmaktadır. Vergi hataları, mükellef veya kamu aleyhine olabilmektedir. Her iki durumda da vergi alacağını etkileyen bir durum söz konusu olduğundan, VUK'da yer alan düzeltme hükümleri uygulanmaktadır. Vergi hataları, hesap hataları ve vergilendirme hataları olarak ikiye ayrılmaktadır. Hesap hatası türleri; matrah hataları, vergi miktarlarındaki hatalar ve verginin mükerrer olması olarak sıralanırken; vergilendirme hataları ise, mükellefin şahsında hata, mükellefiyette hata, mevzuda hata, vergilendirme ve muafiyet döneminde hata olmak üzere dört gruptan oluşmaktadır (VUK md.117-118). Yapılan hatalar mevzuatın öngördüğü şekillerde düzeltilmektedir (VUK md. 120-126). 
Muhasebe hileleri kavramı, VUK’ta açıkça tanımlanmamakla birlikte, VUK'un 359. maddesinde, "Kaçakçıllk Suçları ve Cezaları" başlığı altında ilgili açıklamalara yer verilmiştir. Kanunun ilgili maddesinde muhasebe hileleri yapanlar; “... gerçek olmayan veya kayda konu işlemlerle ilgisi bulunmayan kişiler adına hesap açanlar veya defterlere kaydı gereken hesap ve işlemleri vergi matrahının azalması sonucunu doğuracak şekilde tamamen veya kısmen başka defter, belge veya diğer kaylt ortamlarına kaydedenler,... defter, kayt ve belgeleri tahrif edenler veya gizleyenler veya muhteviyatı itibariyle yanıltıcı belge düzenleyenler veya bu belgeleri kullananlar...” olarak tanımlanmıştır.

Muhasebe hilesi kavramı VUK kapsamında açıkça tanımlanmamakla birlikte, VUK'un 359. maddesinde, kaçakçılık cezasını gerektiren ağır eylemler içerisinde "hesap ve muhasebe hileleri yapmak" da bulunmaktadır. Muhasebede hile, karşı tarafı yanıltma amacı güdülerek, muhasebe kayıt ve işlemlerinde gerçekleştirilen düzensizliklerdir (Alptekin, 2017, s. 9). Hesap hilesi ise; defter veya hesaplarda değişiklik yapmak vasıtasıyla, kurallara aykırılık sonucunu ortaya çıaracak biçimde çeşitli yolsuzlukların üstünü örtmek ve bu işlemlerin hesaplarda ve kayıtlarda ortaya çıkarılmasını zorlaştırıcı ve gizleyici şekilde davranmaktır (Şenyüz, 2017, s. 91). Defter kayıtlarında ve saklanması gereken belgelerde tahrifat yapmak ya da bu belgeleri, ilgili makamlardan gizlemek, yanıltııı ya da sahte belge düzenlemek, defter, kayıt ve belgeleri kısmen ya da tamamen yok etmek de yine suç teşkil eden fiiller kapsamında değerlendirilmiştir (VUK, md. 359). Bu suçlara ilişkin cezai yaptırımlar da yine ilgili madde hükümlerince belirlenmiştir.

\section{Meslek Mensuplarının Muhasebe Hata ve Hilelerine Bakışına İlişsin Bir Araştırma}

Hata ve hile kavramları daha çok meslek etiği çerçevesinde değerlendirilmektedir. Öte yandan vergi kanununda muhasebe hataların azaltılması ve hileye yönelmeyi caydırıcı bir takım düzenlemelere yer verilmiştir. Bu düzenlemelerin muhasebe hata ve hileleri üzerinde, doğrudan ya da dolaylı olarak bir takım etkileri bulunmaktadır. Çalışma kapsamında muhasebe meslek mensuplarının bu etkilere ilişkin değerlendirmeleri araştırılmıştır.

\subsection{Araştırmanın Amacı ve Yöntemi}

Çalışmanın amacı, muhasebe meslek mensuplarının muhasebe hata ve hilelerine bakışlarında, vergi düzenlemelerinin ve vergisel baskıların etkisini değerlendirmektir. Bu kapsamda aşağıdaki araştırma soruları oluşturulmuştur.

AS1: Meslek mensuplarının demografik özelliklerine göre, vergiyi ön planda tutma konusundaki yaklaşımları nasıldır?

AS2: Vergi mevzuat1, mükellefi hata ve hile yapmaya iten veya önleyen faktörlerden biri midir?

AS3: Meslek mensubunun bağımlı ya da bağımsız çalışmasıyla, vergiyi ön planda tutma anlayışı arasındaki ilişki nasıldır?

AS4: Kişileri muhasebe hatası ya da muhasebe hilesi yapmaya iten nedenler nelerdir? Bu hata ve hilelerin önlenmesinde etkili olan faktörler nelerdir?

Çalışma, mevcut durumu tespit etmeye yönelik bir araştırmadır. Araştırma doğrultusunda hazırlanan anket, internet ortamında meslek mensuplarına iletilerek cevapları toplanmıştır. Alanında uzman kişilerin görüşlerine başvurularak hazırlanan anket, 3 kategoriden oluşmaktadır. 1. kategoride demografik sorular yer almış olup, meslek mensuplarının yaşı, eğitim durumu, mesleki tecrübesi ve bağımlı veya bağımsız çalışma durumu sorulmuştur. 2. kategoride sıralama sorularına yer verilmiş, 3. kategoride ise 5'li likert ölçeği kullanılmıştır.

\subsection{Araştırmanın Kısıtları ve Örneklem Seçimi}

Meslek mensuplarının vergi mevzuatı çerçevesinde muhasebe hata ve hilelerine bakışını anlamak amacıyla gerçekleştirilen bu çalışma, İstanbul Serbest Muhasebeci Mali Müşavirler Odası'na kayıtlı SMMM'lerin katılımlarıyla gerçekleştirilmiştir. Odaya kayitlı 43.000 meslek mensubunun 1.018'ine e-posta ve diğer elektronik ortamlar aracılığıyla ulaşılmış olup, anketi yanıtlayarak araştırmaya katılan mali müşavir sayısı 202'dir. Tablo 1'de araştırmaya katılanların yaş, eğitim düzeyi ve mesleki tecrübe bilgilerine yer verilmiştir. 


\begin{tabular}{|l|c|c|c|c|c|}
\hline Tablo 1: Yaş, Eğitim Durumu ve Tecrübe Bilgisi \\
\hline Yaş & Yüzde & Ĕ̈itim Durumu & Yüzde & $\begin{array}{c}\text { SMMM Olarak Geçen } \\
\text { Süre }\end{array}$ & Yüzde \\
\hline $23-24$ & $\% 6$ & Lise & $\% 0,5$ & $1-5$ Y1l & $\% 31,8$ \\
\hline $25-30$ & $\% 22,8$ & Ön Lisans & $\% 1,5$ & $6-10$ Y1 & $\% 27,4$ \\
\hline $31-40$ & $\% 32,8$ & Lisans & $\% 69,2$ & $11-20$ Y11 & $\% 21,4$ \\
\hline $41-50$ & $\% 21,4$ & Lisansüstü & $\% 28,8$ & 21 Y1 ve Üzeri & $\% 19,4$ \\
\hline $51-60$ & $\% 8,5$ & & & & \\
\hline 60 Yaş Üzeri & $\% 8,5$ & & & & \\
\hline
\end{tabular}

\subsection{Bulgular}

Araştırma sonucu elde edilen bulgulara aşağıda yer verilmiştir.

\subsubsection{Meslek Mensuplarının Demografik Özellikleri İle Vergiyi Ön Planda Tutma Anlayışı Arasındaki İlişkinin Değerlendirilmesi (AS1)}

İlk olarak katılımcıların demografik özellikleri ile vergiyi ön planda tutmaya yönelik eğilim göstermeleri arasında ilişki olup olmadığı araştırılmıştır. Bu doğrultuda meslek mensuplarının yaşlarına ve eğitim durumlarına göre verdikleri yanıtlar karşılaştırılmıştır.

\begin{tabular}{|c|c|c|c|}
\hline Yaş Aralığı & $\begin{array}{c}\text { Kesinlikle katılıyorum/ } \\
\text { Katılıyorum (\%) }\end{array}$ & $\begin{array}{c}\text { Kararsızım } \\
(\%)\end{array}$ & $\begin{array}{c}\text { Kesinlikle katılmıyorum/ } \\
\text { Katılmıyorum (\%) }\end{array}$ \\
\hline \multicolumn{4}{|c|}{ İşletmenin muhasebe kayıtlarında yapılan bir hilede, hazinenin vergi kaybı yoksa bu hile diğerlerine göre, daha önemsiz bir hiledir. } \\
\hline 30 yaş ve altı & 33,8 & 20,3 & 45,9 \\
\hline 31-50 yaş arası & 38,5 & 13,7 & 47,8 \\
\hline 51 yaş ve üstü & 20,5 & 11,7 & 67,8 \\
\hline \multicolumn{4}{|c|}{ Belirli oranda vergi ödemek, mükellefi incelenme riskinden korumaktadır. } \\
\hline 30 yaş ve altı & 72,8 & 18,8 & 8,4 \\
\hline 31-50 yaş arası & 57,7 & 15,7 & 26,6 \\
\hline 51 yaş ve üstü & 64,7 & 14,7 & 20,6 \\
\hline \multicolumn{4}{|c|}{ Eğer mükellefin ödeyeceği vergi doğru tahakkuk ettiyse, biçimsel veya usul hatalarının bir önemi yoktur. } \\
\hline 30 yaş ve alt1 & 22 & 3,5 & 74,5 \\
\hline 31-50 yaş arası & 33 & 6,5 & 60,5 \\
\hline 51 yaş ve üstü & 20,5 & 3,1 & 76,4 \\
\hline \multicolumn{4}{|c|}{ Gerekli durumlarda vergiden kaçınma, önemli bir uygulamadır ve yapılmalıdır } \\
\hline 30 yaş ve alt1 & 93,2 & 1,8 & 5 \\
\hline 31-50 yaş arası & 68,8 & 6,5 & 24,7 \\
\hline 51 yaş ve üstü & 79,5 & 5,8 & 14,7 \\
\hline
\end{tabular}

Tablo 2'de yer alan bulgular incelendiğinde, meslek mensupları içinde vergiyi ön planda tutma anlayışının, yaş grupları fark etmeksizin etkin olduğu görülmektedir. Meslek mensuplarının yaş grupları ve eğitim durumları fark etmeksizin; hemen hemen tüm sorulara aynı oranlarda yanıtlar verdikleri görülmektedir. Sadece; hazinenin vergi kaybının bulunmadığ durumlarda hilenin daha önemsiz olduğu görüşüne, 51 yaş ve üzerinde bulunan meslek mensuplarının, daha yüksek bir oranla katılmadıkları görülmektedir. 


\begin{tabular}{|c|c|c|c|}
\hline Eğitim düzeyi & $\begin{array}{c}\text { Kesinlikle katılıyorum/ } \\
\text { Katılıyorum (\%) }\end{array}$ & $\begin{array}{c}\text { Kararsızım } \\
(\%)\end{array}$ & $\begin{array}{c}\text { Kesinlikle katılmıyorum/ } \\
\text { Katılmıyorum (\%) }\end{array}$ \\
\hline \multicolumn{4}{|c|}{ İşletmenin muhasebe kayıtlarında yapılan bir hilede, hazinenin vergi kaybı yoksa bu hile diğerlerine göre, daha önemsiz bir hiledir. } \\
\hline Lise/Ön Lisans & 50 & 25 & 25 \\
\hline Lisans & 38,8 & 14,5 & 46,7 \\
\hline Lisansüstü & 22 & 17 & 61 \\
\hline \multicolumn{4}{|c|}{ Belirli oranda vergi ödemek, mükellefi incelenme riskinden korumaktadır. } \\
\hline Lise/Ön Lisans & 25 & 25 & 50 \\
\hline Lisans & 67,6 & 15,2 & 17,2 \\
\hline Lisansüstü & 55,9 & 18,7 & 25,4 \\
\hline \multicolumn{4}{|c|}{ Eğer mükellefin ödeyeceği vergi doğru tahakkuk ettiyse, biçimsel veya usul hatalarının bir önemi yoktur. } \\
\hline Lise/Ön Lisans & 0 & 25 & 75 \\
\hline Lisans & 33,8 & 4,4 & 61,8 \\
\hline Lisansüstü & 15,2 & 5,2 & 79,6 \\
\hline \multicolumn{4}{|c|}{ Gerekli durumlarda vergiden kaçınma, önemli bir uygulamadır ve yapılmalıdır. } \\
\hline Lise/Ön Lisans & 50 & 0 & 50 \\
\hline Lisans & 78,4 & 5,8 & 15,8 \\
\hline Lisansüstü & 77,9 & 3,5 & 18,6 \\
\hline
\end{tabular}

Bir diğer demografik özellik kriteri eğitim olarak ele alınmış ve sonuçlar Tablo 3’te özetlenmiştir. Araştırmaya katılan lise ve ön lisans mezunu sayısı 4; lisans mezunu sayısı 139 ve lisansüstü mezunu olanların sayısı ise 59'dur. Tablo 3’te görüldüğü gibi lise veya ön lisans mezunlarının bazı sorulara verdikleri yanıtlar, lisans ve lisansüstü mezunlarına göre farklılık göstermekle birlikte, sayılarının çok az olduğu düşünüldüğünde genel olarak eğitim seviyesi ve vergiyi ön planda tutma anlayışı arasında anlamlı bir fark olmadığı sonucu çıkmaktadır.

Yaş ve eğitim seviyelerine ilişkin bulgular birlikte değerlendirildiğinde, katılımcıların çoğunluğunun; hazinenin vergi kaybı yoksa yapılan hilenin diğerlerine göre daha önemsiz olduğu ve bunun yanında, vergi doğru tahakkuk ettiyse biçimsel ve usul hatalarının önemi olmadığı görüşlerine katılmaması, sadece verginin ön planda tutulmadığını göstermektedir. Ancak; belirli oranda vergi ödemenin mükellefi inceleme riskinden koruyacağ1 görüşüne çoğunluğun katıldığ görülmektedir. Bu da meslek mensubunun, yapılan işlemler doğru bile olsa, vergiyi ödememenin olumsuz bir durum yaratabileceği kanısına sahip olduğunu göstermektedir.

\subsubsection{Hata ve Hilede Vergi Etkisinin Değerlendirilmesi (AS2)}

İkinci araştırma sorusu kapsamında meslek mensuplarının, vergi mevzuatının muhasebe hata ve hilelerine yönelik etkisini nasıl değerlendirdikleri, yöneltilen ifadelerle anlaşılmaya çalışılmıştır. Bu kapsamda katılımcılara 6 farklı soru/ifade iletilmiştir. Yanıtların yüzdesel ağırlıklarına Tablo 4'te yer verilmiştir.

Tablo 4: Hata ve Hilede Vergi Etkisinin Değerlendirilmesi

\begin{tabular}{|c|c|c|c|}
\hline Sorular & $\begin{array}{l}\text { Kesinlikle katılıyorum/ } \\
\text { Katılıyorum (\%) }\end{array}$ & $\begin{array}{c}\text { Kararsızım } \\
(\%)\end{array}$ & $\begin{array}{c}\text { Kesinlikle } \\
\text { katılmıyorum/ } \\
\text { Katılmıyorum }(\%)\end{array}$ \\
\hline $\begin{array}{l}\text { Bilanço kalemlerinde, gelir tablosu kalemlerine göre daha fazla } \\
\text { hata yapılmaktadır. }\end{array}$ & 86,5 & 8,4 & 5,1 \\
\hline $\begin{array}{l}\text { Vergi oranlarındaki artışlar, firmaları, muhasebe hilesi yapmaya } \\
\text { itmektedir. }\end{array}$ & 91,6 & 4,3 & 4,1 \\
\hline $\begin{array}{l}\text { Sık mevzuat değişiklikleri (vergi affı, yapılandırma, matrah } \\
\text { artırımı vb.), muhasebe hilesine başvuracak tarafları } \\
\text { cesaretlendirmektedir. }\end{array}$ & 93,5 & 3 & 3,5 \\
\hline $\begin{array}{l}\text { Vergi denetimleri, muhasebe hilelerinin ve vergi kaçakçıllı̆ı } 1 \\
\text { suçlarının ortaya çıkarılması için yeterli sıklıkta yapılmaktadır. }\end{array}$ & 21,4 & 26,4 & 52,2 \\
\hline $\begin{array}{l}\text { Vergi oranlarında yapılacak indirimler muhasebe hilelerini } \\
\text { azaltacaktır. }\end{array}$ & 90 & 5 & 5 \\
\hline $\begin{array}{l}\text { Vergi dönemlerinde yapılacak düzenlemeler hata oranını } \\
\text { azaltacaktır. }\end{array}$ & 82,5 & 9 & 8,5 \\
\hline
\end{tabular}


İlk olarak meslek mensuplarına göre, vergi mevzuatının içerisinde, mükellefi hata veya hileye iten unsurların bulunup bulunmadığı araştırılmıştır. Buradan çıkan sonuç, meslek mensuplarının büyük bir kısmının, vergi mevzuatının içerisinde bu unsurların bulunduğu kanısına sahip olmalarıdır. Vergi oranlarının firmaları hile yapmaya ittiği, af, matrah artırımı vb. uygulamaların muhasebe hilesi yapan tarafları cesaretlendirdiği gibi ifadeler, meslek mensupları tarafından büyük bir çoğunlukla "kesinlikle katılıyorum/katılıyorum” yanıtını almıştır.

İkinci olarak meslek mensuplarına göre; vergi mevzuatının muhasebe hata ve hilelerini önlemeye yönelik faktörlerden biri olup olmadığı araştırılmıştır. Buradaki sonuç da yukarıdaki sonucu destekler niteliktedir. Meslek mensupları içerisinde; muhasebe hata ve hilelerinin mevzuatta sınırlarının çizilmediği, vergi oranları ve vergi takviminde yapılacak değişikliklerin hataları önleyeceği ve vergi denetimlerinin yeterli sıklıkta olmadığı görüşlerinin etkili olduğu görülmektedir.

İkinci araştırma sorusu kapsamında, verginin hata ve/veya hile üzerinde etkileri dışında, vergiye karşı ağırlıklı olarak hangi tepkiler oluştuğu da araştırılmıştır. Katılımcılara, "Vergiye karşı gösterilen yaygın tepkiler nelerdir?” sorusu iletilmiş ve kendilerine göre görülme sıklığı en yaygın olanından, en seyrek olanına doğru sıralamaları istenmiştir.

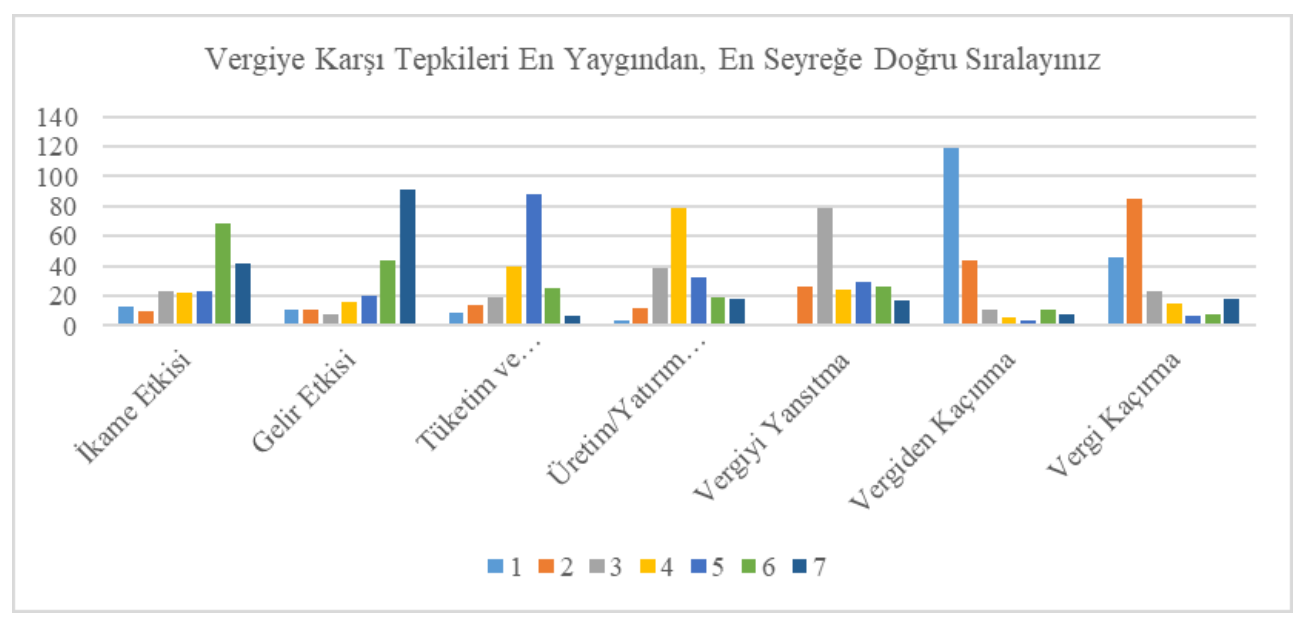

Grafik 1: Vergiye Karşı Tepkilerin Sıralaması

Grafik 1'de vergiye karşı gelişen tepkiler sıralaması yer almaktadır. 202 katılımııın sıralaması; vergiden kaçınma, vergi kaçırma, vergiyi yansıtma, üretimi azaltma ve yatırımdan vazgeçme, tüketim ve tasarrufu kısma, verginin ikame etkisi ve verginin gelir etkisi olarak gerçekleşmiştir. Meslek mensupları vergiye karşı verilen mükellef tepkilerinin en yaygın olanının vergiden kaçınma olduğunu, daha sonra ise vergi kaçırmanın geldiğini düşünmektedir. Vergiden kaçınma yüzde 58,9 oranla birinci sırada yer alırken, vergi kaçırma ise yüzde 22,7 oranla ikinci sırada yer almıştır.

\subsubsection{Meslek Mensuplarının Bağımlı veya Bağımsız Çalışmasıyla, Vergiyi Ön Planda Tutma Anlayışı Arasındaki İlişkinin Değerlendirilmesi (AS3)}

Bu bölümde meslek mensubunun bağımlı ya da bağımsız çalışmasının, vergiyi ön planda tutan bir anlayış benimsemesinde önemli bir rol oynayıp oynamadığı incelenmiştir. Araştırmaya katılan meslek mensuplarından 92'si bağımlı, yani bir şirket bünyesinde çalışırken; 110’u bağımsız olarak çalışmaktadır. Katılımcılara yöneltilen sorular ve bağımlı ya da bağımsız çalışma durumuna göre verilen yanıtların yüzdeleri Tablo 5 'te açıklanmıştır.

Bulgulara göre, bağımlı ya da bağımsız çalışan meslek mensuplarının, vergiyi ön planda tutma anlayışları açısından, benzer görüşlere sahip olduğu görülmektedir. Genel itibariyle, vergiye dönük muhasebe uygulamalarının, meslek mensupları içerisinde etkin olarak var olduğu ortaya çıkmaktadır. Muhasebe hata ve hileleri, meslek mensupları açısından önemli görülse de somut olarak vergiyi ve matrahı etkileyen, hazineyi kayba uğratan hata ve hilelerin, daha çok üstünde durulması gerektiği düşüncesi anketin sonucunun öne çıkardığı bir görüştür. Bu görüşe dayanak yaratan temel sebebin ise, yasada muhasebe hata ve hilelerinin ayrıca tanımlanmayıp, vergi kabahat ve suçları içerisinde, cezai yaptırım olarak karşımıza çıkmasından kaynaklanmış olabileceği düşünülmektedir. 


\begin{tabular}{|c|c|c|c|}
\hline Çalışma şekli & $\begin{array}{l}\text { Kesinlikle katılıyorum/ } \\
\text { Katılıyorum (\%) }\end{array}$ & $\begin{array}{c}\text { Kararsızım } \\
(\%)\end{array}$ & $\begin{array}{c}\text { Kesinlikle katılmıyorum/ } \\
\text { Katılmıorum (\%) }\end{array}$ \\
\hline \multicolumn{4}{|c|}{ İşletmenin muhasebe kayıtlarında yapılan bir hilede, hazinenin vergi kaybı yoksa bu hile diğerlerine göre, daha önemsiz bir hiledir. } \\
\hline Bağımlı & 35,8 & 19,7 & 44,5 \\
\hline Bağımsız & 22,7 & 11,9 & 55,4 \\
\hline \multicolumn{4}{|c|}{ Belirli oranda vergi ödemek, mükellefi incelenme riskinden korumaktadır. } \\
\hline Bağımlı & 66,3 & 16,4 & 71,3 \\
\hline Bağımsız & 57,2 & 16,5 & 26,3 \\
\hline \multicolumn{4}{|c|}{ Eğer mükellefin ödeyeceği vergi doğru tahakkuk ettiyse, biçimsel veya usul hatalarının bir önemi yoktur. } \\
\hline Bağımlı & 28,2 & 6,6 & 65,2 \\
\hline Bağımsız & 27,2 & 3,8 & 69 \\
\hline \multicolumn{4}{|c|}{ Gerekli durumlarda vergiden kaçınma, önemli bir uygulamadır ve yapılmalıdır. } \\
\hline Bağımlı & 83,6 & 3,4 & 13 \\
\hline Bağımsız & 72,7 & 2,3 & 25 \\
\hline
\end{tabular}

\subsubsection{Kişileri Muhasebe Hatası ya da Muhasebe Hilesi Yapmaya İten Faktörlerin Değerlendirilmesi (AS4)}

Çalışmanın dördüncü araştırma sorusunda iki probleme yanıt aranmıştır. Bunlar; meslek mensuplarının bakış açısıyla, tarafları muhasebe hatası ve muhasebe hilesi yapmaya iten faktörlerin neler olduğu ve bunların önlenmesinde etkili olan unsurların hangileri olduğudur. Bu kapsamda katılımcılara bazı soruların yanıtlarını önemliden daha az önemliye doğru sıralamaları istenmiştir. Tablo 6, meslek mensuplarına göre tarafları hata ve hileye iten faktörler sıralamasını, önemliden daha az önemliye doğru sıralanmış olarak göstermektedir. Sıralama sorularında birden fazla şık işaretlenebildiği için toplamlar \%100’ü vermemektedir.

Araştırmanın 1. sorusunda katılımcılara, muhasebe hatalarının ortaya çıkmasında, meslek mensupları açısından etkili olan unsurları, önem sırasına göre, sıralamaları istenmiştir. 202 katılımcının sıralaması; dikkatsizlik, ihmal, bilgisizlik ve tecrübe eksikliği olarak gerçekleşmiştir. Ancak oranların birbirine çok yakın olduğu görülmektedir. Günümüzde teknolojinin gelişmesi eskiden sık rastlanan hata çeşitlerini ortadan kaldırmıştır. Geçmişte tecrübe çok önemli bir konumdayken, muhasebe programlarının mevzuata ve yıl yıl belirlenen standart oranlara hâkimliği, kontrol ve uyarı sistemi geliştirmesi sebebiyle, öne çıkan hata çeşitleri daha farklı olmaktadır. Elbette tecrübe halen, muhasebe mesleği için önem arz etmektedir, ancak düzgün bir şekilde sistemini kuran ve mevzuata hâkim bulunan genç meslek mensupları da kolayca muhasebe sistemine adapte olabilmektedirler. Bu nedenledir ki insan temelli hatalardan meslek mensuplarının öne çıkardığ 1 en önemli faktör dikkatsizlik olmuştur. 


\begin{tabular}{|c|c|c|c|c|}
\hline \multicolumn{5}{|c|}{ Tablo 6: Meslek Mensuplarına Göre, Tarafları Hata ve Hile Yapmaya İten Faktörler } \\
\hline \multicolumn{5}{|c|}{ 1. Muhasebe hatalarının ortaya çıkmasında, meslek mensupları açısından etkili olan unsurlar nelerdir? } \\
\hline Dikkatsizlik & İhmal & Bilgisizlik & \multicolumn{2}{|c|}{ Tecrübesizlik } \\
\hline$\% 48$ & $\% 38,5$ & $\% 38$ & \multicolumn{2}{|c|}{$\% 26$} \\
\hline \multicolumn{5}{|c|}{ 2. Meslek mensupları açısından hatayı artıran faktörler nelerdir? } \\
\hline $\begin{array}{l}\text { Vergi takviminin } \\
\text { sıkışıklığ }\end{array}$ & Mevzuatın anlaşılır olmaması & İşlerin zamanında yapılmaması & İç kontrol yetersizliği & Diğer \\
\hline$\% 65$ & $\% 54$ & $\% 38$ & $\% 36$ & $\% 7$ \\
\hline \multicolumn{5}{|c|}{ 3. En yaygın olarak yapılan hile türleri hangileridir? } \\
\hline $\begin{array}{l}\text { Sahte veya yanıltıcı belge } \\
\text { kullanımı }\end{array}$ & Sahte hesaplar oluşturma & Kayıt dışı işlemler & Zamanı dışında kayıt & Diğer \\
\hline$\% 59$ & $\% 48$ & $\% 44$ & $\% 40$ & $\% 9$ \\
\hline \multicolumn{5}{|c|}{ 4. Hangi grup daha çok muhasebe hilesi yapmaktadır? } \\
\hline İşletme ortakları & İşletme yöneticileri & Muhasebe yetkilileri & \multicolumn{2}{|c|}{ Muhasebe personeli } \\
\hline$\% 54$ & $\% 46$ & $\% 34$ & $\% 16$ & \\
\hline \multicolumn{5}{|c|}{ 5. Çalışanları hileye teşvik eden faktörleri önem sırasına göre sıralayınız. } \\
\hline $\begin{array}{l}\text { Vergi oranlarının } \\
\text { yüksekliği }\end{array}$ & Daha iyi yaşam arzusu & Yönetimsel baskılar & $\begin{array}{l}\text { İç denetim } \\
\text { yetersizlikleri }\end{array}$ & Diğer \\
\hline$\% 59$ & $\% 49$ & $\% 43$ & $\% 42$ & $\% 12$ \\
\hline \multicolumn{5}{|c|}{ 6. İşletme tepe yönetimini hileye iten faktörleri önem sırasına göre sıralayınız. } \\
\hline $\begin{array}{l}\text { Vergi oranlarının } \\
\text { yüksekliği }\end{array}$ & $\begin{array}{c}\text { Mali durumu farklı gösterme } \\
\text { çabas1 }\end{array}$ & Rekabet ortam 1 & \multicolumn{2}{|c|}{ Yatırımcı çekme çabası } \\
\hline$\% 63$ & $\% 35$ & $\% 32$ & $\% 21$ & \\
\hline
\end{tabular}

Araştırmanın 2. sorusunda katılımcılara, meslek mensubunu hatayı artıran faktörleri, önem sırasına göre, sıralamaları istenmiştir. 202 katılımcının sıralaması; vergi takviminin sıkışıklığg, mevzuatın anlaş1lır olmaması, iç kontrol mekanizmasının işletilememesi, işlerin zamanında yapılmaması ve diğer olarak gerçekleşmiştir. Araştırmanın 3. sorusunda katılımcılara, hile türlerinden yaygın olarak hangilerinin yapıldığını önem sırasına göre sıralamaları istenmiştir. Katılımcının sıralaması; sahte ve yanıltıcı belge kullanılması, sahte hesaplar oluşturulması, kayıtların zamanından önce veya sonra yapılması, kayıt dışı işlemler gerçekleştirilmesi ve diğer yanıtları olarak gerçekleşmiştir. 4. soruda katılımcılara en çok hangi grubun hileye yöneldiği sorulmuştur. Katılımcıların tamamının meslek mensubu olduğu düşünüldüğünde, hile yapan tarafın ağırlıklı olarak işletme ortakları ya da yöneticileri olduklarının belirtilmiş olmasının şaşırtıcı olmadığı düşünülmektedir. Öte yandan 5. ve 6. sorular kapsamında iletilen çalışanları ve işletme tepe yönetimini hileye iten faktörlerin sıralanmasında en önemli görülen faktörün vergi oranlarının yüksekliği olması dikkat çekmektedir.

4. araştırma sorusu kapsamında ele alınan bir diğer konu da hata ve hilelerin önlenmesinde etkili olan faktörlerin incelenmesidir. Tablo 7, meslek mensuplarının bu konudaki görüşlerini önem sırasına göre nasıl sıraladıklarını göstermektedir.

\begin{tabular}{|c|c|c|c|c|}
\hline \multicolumn{5}{|c|}{ Muhasebe hatalarının önlenmesi amacıyla alınması gereken önlemleri önem sırasına göre sıralayınız. } \\
\hline $\begin{array}{l}\text { Teknolojiye ve mevzuata uyumlu } \\
\text { güncel muhasebe programlarının } \\
\text { kullanılması }\end{array}$ & $\begin{array}{l}\text { Bilgili ve tecrübeli } \\
\text { personel çalıştırılması }\end{array}$ & $\begin{array}{l}\text { Sürekli eğitim } \\
\text { uygulamaları }\end{array}$ & $\begin{array}{l}\text { İç denetimin } \\
\text { artırılması }\end{array}$ & $\begin{array}{c}\text { Bağımsız denetimin } \\
\text { artırılması }\end{array}$ \\
\hline$\% 62$ & $\% 55$ & $\% 38$ & $\% 28$ & $\% 17$ \\
\hline \multicolumn{5}{|c|}{ Muhasebe hilelerinin önlenmesi amacıyla alınması gereken önlemleri önem sırasına göre sıralayınız. } \\
\hline Vergi oranlarının azaltılması & $\begin{array}{c}\text { Mevzuata ilişkin } \\
\text { düzenlemeler yapılması }\end{array}$ & $\begin{array}{l}\text { Bilgili ve tecrübeli } \\
\text { personel çalıştırılması }\end{array}$ & $\begin{array}{c}\text { İç denetimin } \\
\text { artırılması }\end{array}$ & $\begin{array}{c}\text { Bağımsız denetimin } \\
\text { artırılması }\end{array}$ \\
\hline$\% 63$ & $\% 48$ & $\% 38$ & $\% 29$ & $\% 22$ \\
\hline
\end{tabular}

Muhasebe hatalarının önlenmesinde en önemli faktör, teknolojiye ve mevzuata uygun güncel muhasebe programlarının kullanımı olarak görülürken, çalışanların bilgili ve tecrübeli olması ve bu durumun sürekli eğitimlerle desteklenmesi de diğer önemli faktörler olarak karşımıza çıkmaktadır. Muhasebe hilelerin önlenmesinde ise vergi oranlarının azaltılması önem derecesine göre ilk sırada yer almaktadır. Hilenin ortaya çıkmasında en etkili görülen faktör vergi oranlarının yüksekliği olarak karşımıza çıkarken, benzer şekilde vergi oranlarının azaltılması da hilenin önlenmesinde en önemli 
faktör olarak nitelenmiştir. Bunun yanında mevzuata ilişkin düzenlemeler yapılması da yine yüksek oranda hileyi önlemek amacıyla alınması gereken önlemler arasında değerlendirilmiştir.

\section{Sonuç ve Öneriler}

Muhasebe sistemi, karmaşık bir yapıya sahip bulunmakta ve sistemin işleyişi için çok sayıda kaynaktan beslenmektedir. Bunlar, meslek kanunu, vergi mevzuatı, sosyal güvenlik hukuku, ticaret hukuku gibi kaynaklardır. Ayrıca muhasebe mesleğinin kendi içindeki standartlar, tek düzen hesap planı, finansal raporlama sistemi ve buna benzer birçok örnek sayılabilmektedir. Dolayısıyla muhasebe meslek mensubunun donanımı, bilgi birikimi, eğitim seviyesi, meslek etiğine olan inancı gibi özellikleri, muhasebe sürecinin sağlıklı işlemesi açısından kritik bir öneme sahiptir. Bu nedenle muhasebe hata ve hileleri vergi mevzuatı bakımından değerlendirilirken, hata ve hilenin en önemli unsuru olan meslek mensuplarının görüşleri de araştırmanın içerisine dâhil edilmiştir.

Araştırmadan elde edilen bilgilere göre, muhasebe meslek mensupları arasında, vergiyi ön planda tutan, vergi için muhasebe yapan bir anlayışın yaygın olması dikkat çekmektedir. Bu anlayışın ürünü olan muhasebe sisteminde, 21. yüzyılın genel anlayış ve fikirlerine ters düşen uygulamalar bulunmaktadır. Vergi mevzuatının ve vergi takviminin sürekli olarak son gün uygulamalarıyla, bir iş yoğunluğu ve stres ortamını yaratması, muhasebe meslek mensuplarının bu işi daha profesyonel yapmalarını bir nevi engellemektedir. Araştırmaya katılan meslek mensupları, vergi takviminin sıkışıklığını, sık çıkarılan vergi affı, matrah artırımı uygulamalarını, işletmelerin pratikte kâr veya zarar etmelerine göre değerlendirilmelerini hata ve hileyi doğuran etmenler olarak görmektedir. Dolayısıyla, vergi takviminin daha rahat hale getirilmesi, mevzuatın anlaşılır kılınması ve vergi dönemlerinin düzenlenmesi gerekliliği ön plana çıkmaktadır.

Araştırma kapsamında, tarafları muhasebe hatası ve muhasebe hilesine iten çok sayıda faktör ele alınmış ve açıklanmıştır. Araştırma göstermiştir ki muhasebe meslek mensupları, vergi mevzuatının, en çok da yukarıda sayılan sebeplerle, hata ve hileye zemin hazırladığını düşünmektedir. Ülkemizde vergiye en çok, vergi kaçırma ve vergiden kaçınma fiilleriyle tepki verildiği araştırmanın ortaya koyduğu bir diğer sonuçtur. Mükellefler, çeşitli sebeplerle vergiyi daha az ödeme ya da hiç ödememe yolunu seçmektedirler. Vergi kanunlarında özellikle bu fiil cezalandırılırken ve mevzuatta en çok bu fiile karş1 önlemler alınırken, yaygın olarak işlenen bir suç olması da dikkat çekicidir.

Çağımızın en önemli gelişmeleri teknolojide yaşanmaktadır. Muhasebe sisteminin ve buna uygun olarak yasaların bu duruma uyum sağlaması kritiktir. Dijitalleşen dünyada, bilgisayar sistemleri oldukça önem kazanmış, ülkemizde de artık muhasebe kayıtları kâğıt ortamında değil bilgisayar ortamında yapılmakta, beyannameler internet üzerinden verilmektedir. Çalışmadan da çıkan sonuç, muhasebe hatalarının önlenmesi adına teknolojiye ve mevzuata tam uyumlu bir muhasebe programının kullanılmasının çok önemli oluşudur. Elbette bir gelişmenin olumlu etkisi olduğu gibi, olumsuzlukları da olacaktır. Teknoloji hata ve hileyi azaltmada etkili olsa da hilekârlar da aynı doğrultuda kendilerini geliştirmeye ve elektronik ortamda da muhasebe hilelerini gerçekleştirmeye devam edeceklerdir. Dijital dünyanın getirdiği veri hırsızlığı, hackerlik gibi hile yöntemlerinin örneklerini görmek mümkündür. Bu nedenle işletmelerin teknolojilere yatırım yaparken, veri güvenliğini de ön planda tutmaları önem arz etmektedir.

Muhasebe hilelerini gerçekleştirme güdüsü bulunan birbirinden farklı taraflar varken, tarafların hileye yönelme sebepleri de kişiden kişiye değişebilmektedir. Araştırmanın sonucuna göre; meslek mensupları, muhasebe hilelerinin en çok işletme sahipleri ve yöneticilerinin etkisiyle yapıldığı kanısındadır. Araştırmanın sonucu göstermiştir ki hem çalışanlar hem de işletme sahipleri açısından vergi, hilenin ortaya çıkmasında en önemli faktörlerden biri olarak değerlendirilmektedir. Verginin, tek sonucu işletme sahipleri ya da vergi levhası bulunanlar için gerçekleşmemektedir. Harcamalar üzerinden alınan KDV, ÖTV, Özel İletişim Vergisi, Harçlar, ayrıca servet üzerinden ödenen MTV ve Emlak Vergisi gibi vergiler bütün vatandaşları ilgilendirmektedir. Ücretli çalışanlar da işverenleri aracıllğ̆yla gelir vergisini devlete ödemektedirler. Hilelerinin önüne geçilmesi adına, iç kontrol mekanizmalarının geliştirilmesi, iç denetimlerin artırılması, bağımsız denetim uygulamalarının yaygınlaşması gerekmektedir. 
Çalışma kapsamında, meslek mensuplarının vergiyi ön planda tutma anlayışlarını, demografik özelliklerinin ya da çalışma biçimlerinin etkileyip etkilemediği de araştırılmıştır. Aynı şekilde yaş gruplarının, meslekteki teknolojik gelişmelere bakışı ve muhasebe hata ve hilelerini azaltıcı etkisi bulunup bulunmadığı da anlaşılmaya çalışılmıştır. Çıkan sonuçlar tamamen genel nitelikli olmuştur. Bu da meslek mensuplarının, yaş, eğitim durumu, çalışma biçimi gibi özellikleri fark etmeksizin vergi mevzuatı bakımından hata ve hilelere bakışının aynı doğrultuda olduğunu göstermektedir.

Muhasebe hata ve hilelerinin, vergi mevzuatı yönünden doğru bir şekilde tanımlanması, önlemlerinin alınması, cezai uygulamalarının adil ve caydırıı bir şekilde yasalarda açıkça yer alması gerekliliği bulunmaktadır. İdare, muhasebe hata ve hilelerini ele alırken; sadece vergisel boyutu düşünmemeli, ülke sınırları içerisindeki işletmelerin eşit şartlarda ve ülkeye katma değer sağlayacak şekilde yapılarını oluşturmalarını sağlamalıdır. Dünyanın gelişmişliğine entegre biçimde mali ve finansal verilerini işleyen, muhasebe kayıtlarını doğru ve kurallara uygun tutan işletmeler, bu yolla kurumsallaşma sürecini tamamlayıp hem kendilerine hem de ülke ekonomisine katkı sağlayacaklardır.

Hakem Değerlendirmesi: Dış bağımsız.

Çıkar Çatışması: Yazarlar çıkar çatışması bildirmemiştir.

Finansal Destek: Yazarlar bu çalışma için finansal destek almadığını beyan etmiştir.

Peer-review: Externally peer-reviewed.

Conflict of Interest: The authors has no conflict of interest to declare.

Grant Support: The authors declared that this study has received no financial support.

\section{Kaynakça}

Alptekin, M. (2017). İşletmelerde muhasebe hata ve hilelerinin önlenmesinde kurumsal kaynak planlaması sisteminin kullanımı. Ankara: Gazi Kitabevi.

Batı, M. (2017). Muhasebe hileleri ve vergiden kaçınma Türk vergi mevzuatındaki yasallı̆̆ . Ankara: Seçkin Yayıncılık.

Bayrakl1, H., Erkan, M., \& Elitaş, C. (2012). Muhasebe ve vergi denetiminde muhasebe hata ve hileleri. Bursa: Ekin Yayınevi.

Bozkurt, N. (2016). Işsletmelerin kara deliği hile, çalışan hileleri. İstanbul: Alfa Yayınları.

Crocker, K. J., \& Slemrod, J. (2005). Corporate tax evasion with agency costs. Journal of Public Economics(89), s. 1593-1610.

Çaldağ, Y. (2007). Denetim ve raporlama, finansal tablolar ve analiz teknikleri. Ankara: Gazi Kitabevi.

Doğan, A. (2018). Yargı denetiminde adli muhasebecilik ve hile incelemesi. İstanbul: Beta Yayıncılık.

Erdoğan, M., Elitaş, C., Erkan, M., \& Aydemir, O. (2014). Muhasebe hilelerinin denetiminde Benford yasası. Ankara: Gazi Kitabevi. Maliye Hesap Uzmanları Derneği. (2011). Denetim ilke ve esasları 1. cilt (4. b.). İstanbul: Maliye Hesap Uzmanları Derneği Yayınları. Mengi, B. (2013). Hileli finansal raporlama. İstanbul: Beta Yayınc1lık.

Pehlivanl1, D. (2011). Hile denetimi metodoloji ve raporlama. İstanbul: Beta Yayıncılık.

Singleton, T.W., \& Singleton, A. J. (2010). Fraud auditing and forensic accounting. New Jersey, NJ: Wiley.

Şenyüz, D. (2017). Vergi ceza hukuku. Bursa: Ekin Yayınevi.

Türk Dil Kurumu. (2018, 02 12). Erişim adresi http://www.tdk.gov.tr/index.php?option=com_bts\&arama=kelime\&guid=TDK. GTS.5a81ad3b424fa6.37564244

Vergi usul kanunu.(1961). T.C. Resmi Gazete, (Say1: 10703), 10 Ocak 1961. 